\title{
Respiratory Activity as a Fast Method for Vigor Differentiation of Habanero Pepper Seeds
}

\author{
Elise de Matos Pereira ${ }^{1}$, Aline Silva Freitas ${ }^{1}$, Heloisa Oliveira dos $\operatorname{Santos}^{1}$, Renato Mendes Guimarães ${ }^{1}$, \\ Sophia Mangussi Franchi Dutra ${ }^{1}$, Rucyan Walace Pereira ${ }^{1} \&$ Edila Vilela de Resende Von Pinho ${ }^{1}$ \\ ${ }^{1}$ Departamento de Agricultura, Universidade Federal de Lavras, Lavras, MG, Brazil \\ Correspondence: Heloisa Oliveira dos Santos, Departamento de Agricultura, Universidade Federal de Lavras, \\ CEP: 37200-000 Lavras, MG, Brazil. Tel: 55-353-829-1002. E-mail: heloisa.ufs@gmail.com
}

Received: August 1, 2018

doi:10.5539/jas.v11n2p420

\author{
Accepted: November 3, $2018 \quad$ Online Published: January 15, 2019 \\ URL: https://doi.org/10.5539/jas.v11n2p420
}

\begin{abstract}
The objective of this study was to evaluate the efficiency and rapidity of the Pettenkofer and Titulation methods in the determination of respiratory activity and its relation with the vigor of habanero pepper seeds. For this, six lots of habanero pepper seeds were evaluated for respiratory activity, through Pettenkofer and Titulation physicochemical methods, and for physiological quality via tests of germination, first germination count, germination speed index, emergence, initial stand, emergence speed index and electrical conductivity. Biochemical analyzes were also carried out using the electrophoresis of the esterase (EC 3.1.1.1.) and alcohol dehydrogenase (EC 1.1.1.2.), and the quantification of the endo- $\beta$-mannanase enzyme (EC 3.2.1.78). The tests of physiological quality and the respiratory activity of the seeds allowed the classification of the habanero pepper seed lots at different vigor levels. There was a correlation between the respiratory activity with the tests used to evaluate the physiological quality of the seeds and with the endo- $\beta$-mannanase enzyme. It is concluded that the Pettenkofer and Titulation methods are promising for the evaluation of the deterioration level and the discrimination of lots of habanero pepper seeds with different vigor levels.
\end{abstract}

Keywords: Capisicum chinenses, proteomics, seed respiration, seed vigor

\section{Introduction}

In order to evaluate the physiological quality of seed lots, several tests may be used. The germination test conducted in optimal conditions (temperature, water availability and oxygen) is officially used to evaluate the physiological potential of the seed lots (Brasil, 2009). However, it does not reveal the seeds behavior under field conditions and still does not detect quality differences between lots with high and similar germination pattern (Marcos Filho, 2015).

Therefore, it is relevant to study the vigor of seeds and evaluate them. Thus, vigor tests have been developed with the objective of identifying possible differences in the physiological potential of seed lots and that present characteristics such as simplicity, speed, objectivity and reproducibility, providing complementary information to those obtained in the germination test (Marcos Filho, 2015).

The determination of respiratory activity was reported in some agricultural crops. Papers using the Pettenkofer method in soybean and rice seeds (Mendes et al., 2009) and the titration method (Crispin et al., 1994) have shown that the determination of respiratory activity has been proposed as a promising test to evaluate vigor, since in the deterioration process one of the initial events is the rapid increase in respiration rate (Guimarães, 1999).

Similar studies were conducted with Zea mays L. (Santos et al., 2016), Eruca sativa L. (Torres et al., 2016), Triticum sativum L. (Dode et al., 2016), Citrullus lanatus [Thunb.] Matsum and Nakai (Oliveira et al., 2015) among others, proving the efficiency of the methods in differentiating lots with different vigor levels. However, information about its application in pepper seeds with different levels of vigor and associated to the expression of enzymes has not yet been well studied.

Due to the growing cultivation of peppers in Brazil, there was an increase in demand for high quality seeds. In this sense, it is important to implement a quality control program from production till commercialization. One of 
the demands in these quality control programs is the definition of rapid tests to determine the vigor of seed lots (Santos et al., 2015).

It is worth mentioning that in addition to the rapid tests for vigor determination, the study of the enzymatic processes is another way of evaluating seed quality (Santos et al., 2016). Among the most researched enzymes as markers of physiological quality are those that act in the respiration process, such as alcoholdehydrogenase, enzymes involved in the metabolism of nitrogen-carbon binding (essential in the process of seeds germination). Or even those with specific functions in the metabolism of lipids, as the esterases, which are also linked to the destructuring of the membrane system and also endo- $\beta$-mannanase, a type of cell wall degrading enzyme that plays various roles in different developmental events.

In this context, the objective of this study was to evaluate the efficiency and rapidity of the Pettenkofer and Titulation methods in determining the respiratory activity and its relation with the vigor of habanero pepper seeds (Capsicum chinenses).

\section{Material and Methods}

Six lots of habanero pepper seeds (Capsicum chinenses Jacquin) were used. The seeds were submitted to the following tests and determinations:

The water content of the seeds was determined by the oven method at $105^{\circ} \mathrm{C}$ for $24 \mathrm{~h}$, using two subsamples for each treatment, according to the Rules for Seed Analysis-RAS (Brasil, 2009). The results were expressed as percentage.

The germination test was performed with four replications of 50 seeds sown on two sheets of blotting paper, moistened with water in the ratio of three times the weight of the dry substrate, in gerbox plastic boxes. These were kept in B.O.D germination chambers under alternating temperature and light conditions, being $20^{\circ} \mathrm{C} / 16 \mathrm{~h}$ in the dark and $30^{\circ} \mathrm{C} / 8 \mathrm{~h}$ in the presence of light. The counts were made at 7 and 14 days after sowing (Brasil, 2009) and the results expressed as percentage of normal seedlings. The first count and germination speed index (GSI) tests were conducted together with the germination test; for the first count, the normal seedling percentages were recorded at seven days after sowing, as prescribed in the RAS, and for the GSI were carried out daily readings of the number of normal seedlings.

For the emergence, were used four replications of 50 seeds distributed in multicellular trays of polystyrene with separate cells containing commercial substrate. The trays were kept in a greenhouse equipped with an intermittent misting system, at a temperature from 25 to $30{ }^{\circ} \mathrm{C}$. Daily evaluations were carried out from the beginning of the emergence of seedlings, counting the number of emerged seedlings until the stabilization of the stand. It was computed the number of normal seedlings at the beginning of the emergence to calculate the initial stand and at 30 days for the calculation of the emergence percentage. For the calculation of the emergence speed index (ESI), according to Maguire (1962), were performed daily readings of the number of seedlings with the cotyledonary leaves above the ground.

The electrical conductivity test was conducted in the mass system with four replications of 50 seeds. They were weighted with the accuracy of two decimal places, and then placed in disposable plastic cups with $25 \mathrm{~mL}$ of distilled water. After $24 \mathrm{~h}$ of soaking at $25^{\circ} \mathrm{C}$, the electrical conductivity was determined using a conductivity meter with results that were expressed in $\mu \mathrm{S} \mathrm{cm}^{-1} \mathrm{~g}^{-1}$, according to the method described by Panobianco \& Marcos Filho (1998).

The titulation method for the conduction of the respiration test was composed of transparent plastic gerbox type boxes, containing tray of thin netting, used as support for the seeds. At the bottom of each gerbox were placed 40 $\mathrm{mL}$ of $\mathrm{KOH}$ solution at $0.1 \mathrm{~N}$. To avoid gas exchange with the medium, each gerbox was sealed with PVC film. Each one of the four replications of 50 seeds was placed on the netting containing a sheet of blotting paper moistened twice of its dry weight. The gearboxes were kept in a germinating chamber, B.O.D. type, for a period of $24 \mathrm{~h}$ at a constant temperature of $25^{\circ} \mathrm{C}$.

After this period, a $25 \mathrm{~mL}$ sample of the $\mathrm{KOH}$ solution, per replication, received drops of phenolphthalein color dye and titrated with $\mathrm{HCl}$ at $0.1 \mathrm{~N}$. At the turning point, the volume of $\mathrm{HCl}$ spent on each of the tested replications was recorded. This volume of $\mathrm{HCl}$ that is directly related to the amount of $\mathrm{CO}_{2}$ fixed by the $\mathrm{KOH}$ solution comes from respiration. The calculation of the respiratory activity was done based on the following equation: 


$$
(\mathrm{B}-\mathrm{L}) \times \mathrm{C} / \mathrm{MS}
$$

where, B: blank test reading $(\mathrm{mL})$; $\mathrm{L}$ : reading of $\mathrm{HCl}$ volume spent to neutralize $\mathrm{KOH}$ submitted to respiration $(\mathrm{ml})$; C: correlation factor (3.52); MS: dry matter of the seeds (mg).

The results were expressed in $\mathrm{mg}$ of $\mathrm{CO}_{2}$ per gram of dry seed (Crispim et al., 1994).

Respiratory activity was determined by means of the Pettenkofer apparatus, which consists of four flushing flasks; two of them contain sodium hydroxide $(\mathrm{NaOH})$ at $25 \%$ which is intended to retain $\mathrm{CO}_{2}$ from medium air; one flask for storage of the seeds under study, free of $\mathrm{CO}_{2}$ from medium air; and one containing barium hydroxide $\left(\mathrm{Ba}(\mathrm{OH})_{2}\right)$ at $25 \%$, which reacts with $\mathrm{CO}_{2}$ from the respiratory activity of the seeds, resulting in barium carbonate $\left(\mathrm{BaCO}_{3}\right)$. The flasks are interconnect by a silicone hose coupled to an air aspirating tube, whose flow is regulated by a valve, allowing the control of its speed by observing the bubbles formed in the flasks.

The seeds of the different lots were placed in the storage flask at $25^{\circ} \mathrm{C}$; after $2 \mathrm{~h}$ of exposure of seeds, two aliquots of the supernatant were removed for titration. In each aliquot were added two drops of phenolphthalein reagent and then titrated with $0.1 \mathrm{~N}$ hydrochloric acid $(\mathrm{HCl})$. The volume of $\mathrm{HCl}$ used up to the turning point is proportional to the amount of $\mathrm{BaCO}_{3}$ present in the solution, which is also proportional to the amount of $\mathrm{CO}_{2}$ originating from the respiratory activity of the seeds. The calculation of the respiratory activity was performed based on the following equation:

$$
(\mathrm{Lb}-\mathrm{La}) \times\left(1.1 \times 10^{5} / \mathrm{h} \times \mathrm{g}\right)
$$

where, Lb: blank test reading $(\mathrm{mL})$; La: sample reading $(\mathrm{mL})$; h: waiting time in the apparatus (hours); g: seed mass used (mg).

The result was expressed as the amount of carbon dioxide released per gram of seed per hour $\left(\mu \mathrm{g} \mathrm{CO}_{2} \mathrm{~g} \mathrm{seed}^{-1}\right.$ $\left.\mathrm{h}^{-1}\right)$.

The crude enzymatic extracts were obtained by the maceration of the seeds in the presence of PVP (polyvinylpyrrolidone) and liquid nitrogen in crucible, and later stored at $-86{ }^{\circ} \mathrm{C}$. The electrophoretic run was performed in a discontinuous system of polyacrylamide gel at $7.5 \%$ (separator gel) and at $4.5 \%$ (concentrator gel). The gel/electrode system used was Tris-glycine ( $\mathrm{pH} 8.9$ ). It was put to the gel channel $50 \mu \mathrm{l}$ of the sample supernatant and the run performed at $150 \mathrm{~V}$ for $5 \mathrm{~h}$. At the end of the run, the gels were revealed for the enzymes alcohol dehydrogenase (ADH) and esterase (EST) (Alfenas, 2006).

For the extraction of the endo- $\beta$-mannanase enzyme, $300 \mu \mathrm{L}$ of extraction buffer $(0.1 \mathrm{M}$ Hepes $/ 0.5 \mathrm{M} \mathrm{NaCl}$ and ascorbic acid (5 mg of ascorbic acid per $\mathrm{mL}$ of buffer), $\mathrm{pH} \mathrm{8.0)}$ was added to each micro tube with $100 \mathrm{mg}$ of powder of each sample. In the next step, the samples were centrifuged for $30 \mathrm{~min}$ at $14000 \mathrm{rpm}$ and $2 \mu \mathrm{l}$ of the supernatant were put on gel containing $6 \mathrm{~mL}$ of LBG (Locust Bean Gum), $0.24 \mathrm{~g}$ of agarose and $24 \mathrm{~mL}$ of pH 5.0 buffer ( $1 \mathrm{M}$ Citric Acid/ $0.4 \mathrm{M}$ of $\mathrm{Na}_{2} \mathrm{HPO}_{4} \cdot 2 \mathrm{H}_{2} \mathrm{O}$ ). The aliquots were applied in $2 \mathrm{~mm}$ holes made in the gel with the aid of a punch. The gel was incubated for $21 \mathrm{~h}$ and revealed according to the methodology proposed by Silva et al. (2004). Endo- $\beta$-mannanase enzyme activity was calculated according to Downie, Hillhorst, and Bewley (1994).

The experimental design was completely randomized with four replications. The germination, vigor, and endo- $\beta$-mannanase enzyme data, previously submitted to the residue normality tests and the homoscedasticity of the variances, were submitted to variance analysis using the Sisvar ${ }^{\circledR}$ software (Ferreira, 2014), and the means compared among them by Scott-Knott's test, at $\mathrm{p}<0.05$. It was done the correlation analysis of each vigor test with the Pettenkofer method and the Titration method, using the software Assistat-Version 7.5 Beta (Silva \& Azevedo, 2002).

\section{Results and Discussion}

The moisture content of the seeds from six lots of habanero pepper (Table 1) was similar for all lots, with no difference. This small variation in the moisture degree among the lots is important for the execution of tests to evaluate the quality of seeds, since uniformity is essential for the standardization of evaluations and obtaining consistent results (Marcos Filho, 2015). 
Table 1. Moisture content of dryed seeds and soaked seeds for six lots of habanero pepper seeds

\begin{tabular}{llll}
\hline Specie & Lots & Dryed (\%) & $(\%)$ \\
\hline & 1 & 8.5 & 24 \\
Habanero Pepper & 2 & 8.4 & 22 \\
& 3 & 8.2 & 20 \\
& 4 & 8.3 & 20 \\
& 5 & 8.5 & 23 \\
& 6 & 8.4 & 22 \\
\hline
\end{tabular}

The germination test allowed the habanero pepper lots to be grouped into two levels of vigor, with lots $01,02,03$ and 04 being superior to the others and lot 06 with reduced quality (Table 2). These results are consistent with those reported by Dutra et al. (2016); they observed that the behavior among lots of pepper was significantly different when evaluated by the germination test.

Table 2. Vigor tests: médium values of germination (G), first count of germination (FC), germination speed index (GSI) for six lots of habanero pepper seeds

\begin{tabular}{lllll}
\hline Specie & Lots & Germination (\%) & First count of germination (\%) & GSI \\
\hline \multirow{4}{*}{ HabaneroPepper } & 1 & $(76.0) \mathrm{a}$ & $(28.0) \mathrm{c}$ & $(21.9) \mathrm{a}$ \\
& 2 & $(77.0) \mathrm{a}$ & $(25.0) \mathrm{c}$ & $(15.9) \mathrm{b}$ \\
& 3 & $(87.0) \mathrm{a}$ & $(41.0) \mathrm{b}$ & $(25.8) \mathrm{a}$ \\
& 4 & $(86.0) \mathrm{a}$ & $(52.0) \mathrm{a}$ & $(28.1) \mathrm{a}$ \\
& 5 & $(48.0) \mathrm{b}$ & $(21.0) \mathrm{d}$ & $(14.8) \mathrm{b}$ \\
& 6 & $(46.0) \mathrm{b}$ & $(16.0) \mathrm{d}$ & $(07.5) \mathrm{c}$ \\
\hline
\end{tabular}

Note. Means followed by the same letter in the column do not differ by the Scott-Knott test at $\mathrm{p}<0.05$.

By means of the tests of first germination count and GSI (Table 2), it was possible to separate lots 04 as better quality and lot 06 as worse quality. The first germination count test is generally used as a vigor test because of its simplicity and for being conducted along with the germination test. The germination speed can be used to identify cultivars with seeds that present a faster emergence in the field or in the greenhouse, thus minimizing the adverse conditions that occur during germination and seedling establishment (Oliveira et al., 2015).

Regard to the initial stand vigor, emergence and ESI tests, there was a low variation among habanero pepper lots, with lot 04 being superior and lot 06 being inferior than the others (Table 3).

Table 3. Vigor tests: médium values of initial stand (IS), emergence (E) and emergence speed index (ESI) for six lots of habanero pepper seeds

\begin{tabular}{lllll}
\hline Specie & Lots & Initial stand (\%) & Emergence (\%) & ESI \\
\hline & 1 & $(48.0) \mathrm{a}$ & $(52.0) \mathrm{a}$ & $(9.4) \mathrm{a}$ \\
& 2 & $(48.0) \mathrm{a}$ & $(53.0) \mathrm{a}$ & $(9.8) \mathrm{a}$ \\
Habanero Pepper & 3 & $(49.0) \mathrm{a}$ & $(51.0) \mathrm{a}$ & $(9.4) \mathrm{a}$ \\
& 4 & $(51.0) \mathrm{a}$ & $(56.0) \mathrm{a}$ & $(9.0) \mathrm{a}$ \\
& 5 & $(47.0) \mathrm{a}$ & $(53.0) \mathrm{a}$ & $(9.5 \mathrm{a}$ \\
& 6 & $(35.0) \mathrm{b}$ & $(40.0) \mathrm{b}$ & $(6.2) \mathrm{b}$ \\
\hline
\end{tabular}

Note. Means followed by the same letter in the column do not differ by the Scott-Knott test at $\mathrm{p}<0.05$.

It is worth mentioning that the propagation of pepper is made by seeds. However, there is a need to adopt the practice of transplanting seedlings, so the emergence, ESI and initial stand tests are fundamental to presume the seed performance in the seedlings establishment. 
The behavior among lots of habanero pepper was not significantly different when evaluated by the electrical conductivity test (Table 4). Generally, very low water contents, less than or equal to $10 \%$, or very high, higher than or equal to $17 \%$, influence the results of electrical conductivity, so, they should be adjusted to a water content range between $10 \%$ and $17 \%$,before testing for obtaining comparable results (AOSA, 1983).

Table 4. Medium values of electrical conductivity (EC), respiratory taxes activity by the Pettenkofer method, and by the Titulation method for six lots of habanero pepper seeds

\begin{tabular}{lllll}
\hline Specie & Lots & $\begin{array}{l}\text { Electrical conductivity } \\
\left(\mu \mathrm{S} \mathrm{cm}^{-1} \mathrm{~g}^{-1}\right)\end{array}$ & $\begin{array}{l}\text { Pettenkofer } \\
\left(\mu \mathrm{g} \mathrm{CO}_{2} \mathrm{~g} \mathrm{seed}^{-1} \mathrm{~h}^{-1}\right)\end{array}$ & $\begin{array}{l}\text { Titulation } \\
\left(\mathrm{mg} \mathrm{O}_{2} \mathrm{~g} \mathrm{seed}^{-1}\right)\end{array}$ \\
\hline \multirow{3}{*}{ Habanero Pepper } & 1 & $(21.4) \mathrm{a}$ & $(29.30) \mathrm{c}$ & $(46.15) \mathrm{c}$ \\
& 2 & $(21.9) \mathrm{a}$ & $(28.35) \mathrm{d}$ & $(49.73) \mathrm{d}$ \\
& 3 & $(23.8) \mathrm{a}$ & $(39.80) \mathrm{a}$ & $(30.13) \mathrm{b}$ \\
& 5 & $(24.4) \mathrm{a}$ & $(37.38) \mathrm{b}$ & $(25.48) \mathrm{a}$ \\
& 6 & $(23.7) \mathrm{a}$ & $(16.60) \mathrm{e}$ & $(55.60) \mathrm{e}$ \\
& $\mathrm{CV}(\%)$ & 7.76 & $(14.33) \mathrm{f}$ & $(59.15) \mathrm{f}$ \\
\hline
\end{tabular}

Note. Means followed by the same letter in the column do not differ by the Scott-Knott test at $\mathrm{p}<0.05$.

By the respiratory activity measured by Pettenkofer physicochemical method (Table 4), in which is evaluated the amount of $\mathrm{CO}_{2}$ released by the respiration of the seeds per gram of seed per hour, it was possible to statistically separate all the seed lots in six levels of vigor. Similar behavior was found by Torres et al. (2016) and Dode et al. (2016) that, working with E. sativa and T. sativum, respectively, verified the efficiency of the Pettenkofer method in statistically separating lots at quality levels.

Lot 06 showed the lowest respiration by both the Pettenkofer method and the titulation method, with $14.33 \mu \mathrm{g}$ $\mathrm{CO}_{2} \mathrm{~g} \mathrm{seed}^{-1} \mathrm{~h}^{-1}$ and $59.15 \mathrm{mg} \mathrm{O}_{2} \mathrm{~g} \mathrm{seed}^{-1}$ respectively, and was statistically inferior to the other lots, evidencing the low performance of this lot also in the other vigor tests (Table 4).

By the respiration rate determined by the titulation method, which evaluates the amount of $\mathrm{O}_{2}$ released by the respiration of the seeds, it was possible to statistically separate all lots at six levels of vigor, as observed for the Pettenkofer test.

It should be emphasized that the results found in the respiration tests presented the same tendency as in the other vigor tests used to express the performance of the physiological quality, as well as distinguished the lots of pepper seeds at different vigor levels. Likewise, through Pettenkofer method was verified the same behavior for both soybean and bean seeds (Martins et al., 2014). In another study with soybean seeds, the titration method indicated compatible results with other tests to determine the physiological quality and proved to be feasible for use in evaluating the respiratory rate (Crispin et al., 1994).

The activity and integrity of the mitochondria of viable embryos increase from the beginning of the imbibition, which makes the production of ATP more efficient, reflecting the increase of the oxygen consumption and consequent increase in the production of carbon dioxide (Bewley \& Black, 1994). Thus, the more vigorous lot tends to increase the respiration rate more than lots with less vigor, over the same period of time. We can still infer that the time of imbibition of the seeds (two hours) and the permanence in the Pettenkofer apparatus (two hours) was sufficient to allow the separation of the lots, taking into account their physiological quality identified through the reference tests used in this research.

Regarding to the endo- $\beta$-mannanase enzyme, it can be observed by the results that there are differences in the enzyme activity when determined in dry seeds and germinated seeds (Table 5). Thus, when evaluated in seeds considered germinated, the activity of the enzyme is markedly higher than the activity in the dry seeds.

The endo- $\beta$-mannanase enzyme is an important germination-regulating mechanism being directly related to the softening process of the endosperm, which hydrolyzes the cell wall (González-Calle et al., 2015). 
Table 5. Endo- $\beta$-mannanase enzyme activity determined in dry seeds and germinated seeds for six lots of habanero pepper seeds

\begin{tabular}{llll}
\hline & \multirow{2}{*}{ Lots } & \multicolumn{2}{c}{ endo- $\beta$-mannanase enzyme activity $\left(\right.$ picomol $\left.\mathrm{min}^{-1} \mathrm{~g}^{-1}\right)$} \\
\cline { 2 - 3 } & 1 & Dry seeds $(8 \%)$ & Germinated seeds $(4$ days $)$ \\
\hline \multirow{3}{*}{ Habanero Pepper } & 2 & $(10.47) \mathrm{c}$ & $(19.34) \mathrm{c}$ \\
& 3 & $(10.34) \mathrm{c}$ & $(18.80) \mathrm{c}$ \\
& 5 & $(12.50) \mathrm{a}$ & $(23.97) \mathrm{a}$ \\
& 6 & $(12.14) \mathrm{b}$ & $(16.57) \mathrm{d}$ \\
& $\mathrm{CV}(\%)$ & $(7.30) \mathrm{e}$ & $(15.47) \mathrm{e}$ \\
\end{tabular}

Note. Means followed by the same letter in the column do not differ by the Scott-Knott test at $\mathrm{p}<0.05$.

Analyzing the linear correlations (Table 6) among the tests used to evaluate the physiological quality of pepper seeds, there was a significant correlation between the results of the respiratory activity measured by the Pettenkofer method with germination (r) of 0.9793, the first emergence count with (r) of 0.8901 and, (r) of 0.9297 for GSI. The same was observed about the titration method with simple linear correlation with (r) of -0.8729 for the germination test, first emergence count and IVG with (r) of -0.9869 and -0.9433 , respectively. Besides, the respiration tests were correlated with each other with (r) of -0.9393 . This means that both tests confirmed the respiratory actitivity and the negative correlation can be because the titration method measured the quantity of $\mathrm{O}_{2}\left(\mathrm{mg} \mathrm{O}_{2} \mathrm{~g} \mathrm{seed}^{-1}\right)$ and the Pettenkofer method the quatity of $\mathrm{CO}_{2}\left(\mu \mathrm{g} \mathrm{CO}_{2} \mathrm{~g} \mathrm{seed}^{-1} \mathrm{~h}^{-1}\right)$.

Table 6. Coefficient of simple correlation (r) between germination (G), first count of germination (FC), germination speed index (GSI), initial stand (IS), emergence in trays (E), emergence speed index (ESI), electrical conductivity (EC), respiratory taxes activity by the Pettenkofer (Pett) method, and by the Titulation method and endo- $\beta$-mannanase enzyme activity for six lots of habanero pepper seeds

\begin{tabular}{|c|c|c|c|c|c|c|c|c|c|}
\hline & $\mathrm{FC}$ & GSI & IS & E & ESI & $\mathrm{EC}$ & Pett. & Titulation & Endo $\beta$ \\
\hline G & $0.827 *$ & $0.8827 *$ & $0.7594^{\mathrm{ns}}$ & $0.6256^{\mathrm{ns}}$ & $0.5767^{\mathrm{ns}}$ & $-0.0529^{\mathrm{ns}}$ & $0.9793 * *$ & $-0.8729 *$ & $0.9681 * *$ \\
\hline $\mathrm{FC}$ & & $0.9304 * *$ & $0.7083^{\mathrm{ns}}$ & $0.6249^{\mathrm{ns}}$ & $0.3837^{\mathrm{ns}}$ & $-0.5450^{\mathrm{ns}}$ & $0.8901^{*}$ & $-0.9869 * *$ & $0.8990^{*}$ \\
\hline GSI & & & $0.8527^{*}$ & $0.7476^{\text {ns }}$ & $0.6104^{\mathrm{ns}}$ & $-0.3357^{\mathrm{ns}}$ & $0.9279 * *$ & $-0.9433 * *$ & $0.9506 * *$ \\
\hline IS & & & & $0.9705 * *$ & $0.9180^{*}$ & $-0.1722^{\mathrm{ns}}$ & $0.7551^{\mathrm{ns}}$ & $-0.7014^{\mathrm{ns}}$ & $0.8213^{*}$ \\
\hline $\mathrm{E}$ & & & & & $0.9039 *$ & $-0.1753^{\mathrm{ns}}$ & $0.6061^{\mathrm{ns}}$ & $-0.5833^{\mathrm{ns}}$ & $0.6860^{\mathrm{ns}}$ \\
\hline ESI & & & & & & $-0.0711^{\mathrm{ns}}$ & $0.5413^{\text {ns }}$ & $-0.3980^{\mathrm{ns}}$ & $0.6186^{\mathrm{ns}}$ \\
\hline $\mathrm{EC}$ & & & & & & & $0.2208^{\mathrm{ns}}$ & $-0.5013^{\mathrm{ns}}$ & $0.2566^{\mathrm{ns}}$ \\
\hline Pett & & & & & & & & $-0.9393 * *$ & $0.9932 * *$ \\
\hline Titulation & & & & & & & & & $0.9406 * *$ \\
\hline
\end{tabular}

Note. ${ }^{*}$ Significant at $1 \%$, significant at $5 \%$ and ${ }^{\mathrm{ns}}$ not significant at $5 \%$.

The results obtained were similar to those obtained by Santos et al. (2016) who verified significant correlations between the physiological quality of seeds of maize hybrids and the respiratory activity evaluated by the Pettenkofer and titration methods.

In wheat seeds, the results allowed to relate the quality standard tests of the seed lots with the respiratory activity measured in the Pettenkofer apparatus (Dode et al., 2016). However, there were no significant correlations between respiration and vigor tests in watermelon seeds (Oliveira et al., 2015).

The activity of the endo- $\beta$-mannanase enzyme was significantly correlated with germination, first germination count, IVG, initial stand, Titulation method and with the Pettenkofer method. The correlation between the Pettenkofer method and the enzyme activity was the highest observed, (r) of 0.9932 (Table 6).

Thus, the determination of the activity of this enzyme in dry and germinated seeds allows the differentiation of seed lots with different levels of physiological quality. 
It was observed significant changes in the activity of the alcohol dehydrogenase enzyme (ADH) in both dry and imbibed seeds for all the pepper seed lots, with dry seeds showing higher enzymatic activity (Figure 1).

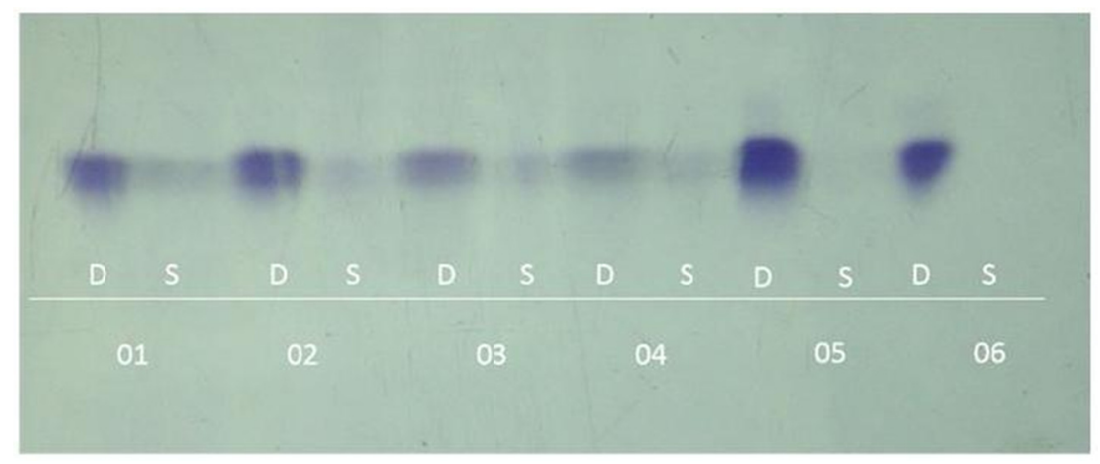

Figure 1. Expression of enzyme alcohol dehydrogenase (ADH) determined in dry seeds and soaked seeds of six lots of habanero pepper seeds with different levels of vigor

It should be noted that this enzyme is related to anaerobic respiration, promoting the reduction from acetaldehyde to ethanol (Buchanan et al., 2005). In the Bowdichia virgilioides seeds, it was observed that as the seeds were exposed to imbibition, the tegument became more permeable, thus allowing the supply of oxygen, justifying the decrease of the intensity of the bands of the ADH enzyme (Albuquerque et al., 2009).

In rice seeds, two alleles of the ADH enzyme were observed, with exclusive expression in the dry seeds, evidencing that as the germination process develops and the aerobic process of energy generation begins to predominate, the $\mathrm{ADH}$ is no longer necessary (Malone et al., 2007).

In the case of pepper, the alcohol dehydrogenase enzyme was shown to be a good indicator of the reduction in seed quality, especially when the seeds were highly deteriorated, as evidenced by the germination test and the respiratory analyzes (Tables 2 and 4).This result contrasts with that observed for sweet corn seeds, which the isoenzymatic profiles revealed to ADH non alteration in the number and intensity of bands that could be associated to the reduction observed in the physiological quality of the seeds (Camargo \& Carvalho, 2008).

According to the electrophoretic patterns of the esterase enzyme, it is possible to observe a higher activity of this enzyme in imbibed seeds, in all lots and with the appearance of isoforms. It can be observed an increase in the expression of this enzyme in lots 03 and 04, which have higher values of germination and vigor (Figure 2).

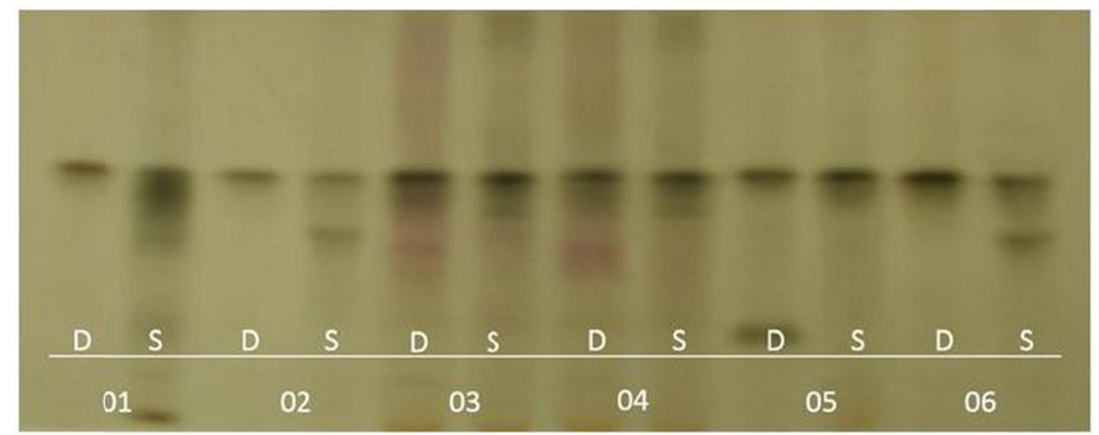

Figure 2. Expression of enzyme esterase (EST) determined in dry seeds and soaked seeds of six lots of habanero pepper seeds with different levels of vigor

This group of hydrolytic enzymes releases lipid fatty acids, which are used in $\beta$ - oxidation, as a source of energy for germination events (Silva et al., 2004). Thus, it is inferred that the lipids present in the seeds were used as energy source during the germination process. It is worth mentioning that Caixeta et al. (2014) found similar results in chili pepper seeds during development and storage, that is, after the imbibition, a greater accumulation of the esterase enzyme is observed. 
In this paper, it was characterized the importance of evaluating the respiratory activity of seeds in addition to the germination test and vigor tests, for the evaluation of the physiological quality of seeds, confirming that the Pettenkofer and Titration methods, to determine the respiratory rate, can be promising because they are simple, practical and inexpensive to differentiate seed lots.

\section{Conclusion}

The use of Pettenkofer and Titration methods for the determination of respiratory activity are efficient, fast and provide vigor differentiation of seed lots of habanero pepper.

\section{Acknowledgements}

The authors thank the Foundation for Research Support of the State of Minas Gerais (FAPEMIG), the Coordination for the Improvement of Higher Education Personnel (CAPES), and The National Council for Scientific and Technological Development (CNPq), for financial support and scholarships.

\section{References}

Albuquerque, K. S., Guimarães, R. M., Almeida, I. F., \& Clemente, A. D. C. S. (2009). Alterações fisiológicas e bioquímicas durante a embebição de sementes de sucupira-preta. Revista Brasileira de Sementes, 31(1), 12-19. https://doi.org/10.1590/S0101-31222009000100028

Alfenas, A. C. (2006). Eletroforese e marcadores bioquímicos em plantas e microrganismos (p. 627). Viçosa: Editora UFV.

AOSA (Association of Official Seed Analysts). (1983). Seed vigour testing handbook. East Lasing.

Bewley, J. D., \& Black, M. (1994). Seeds: Physiology of development and germination (p. 445). New York: Plenum. https://doi.org/10.1007/978-1-4899-1002-8

Brasil. (2009). Regras para análise de sementes (p. 399). Ministério da Agricultura e Reforma Agrária, Coordenação de Laboratório Vegetal.

Buchanan, B. B., Gruissem, W., \& Jones, R. L. (2005). Biochemistry e molecular biology of plants (p. 451). Rockville: American Society of Plant Physiologists.

Caixeta, F., Von Pinho, E. V. D. R., Guimarães, R. M., Pereira, P. H. A. R., Catão, H. C. R. M., \& Clemente, A. D. C. S. (2014). Determinação do ponto de colheita na produção de sementes de pimenta malagueta e alterações bioquímicas durante o armazenamento e a germinação. Científica, 42(2), 187-197. https://doi.org/10.15361/1984-5529.2014v42n2p187-197

Camargo, R., \& Carvalho, M. L. M. (2008). Armazenamento a vácuo de semente de milho doce. Revista Brasileira de sementes, 30(1), 131-139. https://doi.org/10.1590/S0101-31222008000100017

Crispin, J. E., Martins, J. C., Pires, J. C., Antonio, C., \& Cavariani, R. E. C. (1994). Determinação da taxa de respiração em sementes de soja pelo método da titulação. Pesquisa Agropecuária Brasileira, 29(10), 1517-1521.

Dode, J., da Silva A. A., Deuner, C., Borges, C. T., Meneghello, G. E., Villela, F. A., \& de Moraes, D. M. (2016). Respiratory activity in wheat seeds as related to physiological quality. Bioscience Journal, 32, 1246-1253. https://doi.org/10.14393/BJ-v32n5a2016-33001

Downie, B., Hilhorst, H. W. M., \& Bewley, J. D. (1994). A new assay for quantifying endo- $\beta$-mannanase activity using Congo Red dye. Phytochemistry, 36, 829-835. https://doi.org/10.1016/S0031-9422(00)90446-1

Dutra, S. M. F., Von Pinho, E. V. R., Santos, H. O., Pereira, E. M., Lima, A., \& Guimarães, R. M. (2016). Pettenkofer method for assessing the quality of Habanero pepper seeds. Research International Journal of Current Research, 8, 27115-27119. https://doi.org/10.5897/AJAR2015.10462

Ferreira, D. F. (2014). Sisvar: A guide for its bootstrap procedures in multiple comparisons. Ciência e Agrotecnologia, 38(2), 109-112. https://doi.org/10.1590/S1413-70542014000200001

González-Calle, V., Barrero-Sicilia, C., Carbonero, P., \& Iglesias-Fernández, R. (2015). Mannans and endo- $\beta$-mannanases (MAN) in Brachypodium distachyon: expression, profiling and possible role of the BdMAN genes during coleorhiza-limited seed germination. Journal of Experimental Botany, 66(13), 3753-3764. https://doi.org/10.1093/jxb/erv168

Guimarães, R. M. (1999). Fisiologia de sementes (p. 219). Lavras: UFLA/FAEPE. 
Maguire, J. D. (1962). Speed of germination: Aid in selection and evaluation for seedling emergence and vigor. Crop Science, 2(1), 176-177. https://doi.org/10.2135/cropsci1962.0011183X000200020033x

Malone, G., Zimmer, P. D., Meneghello, G. E., Castro, M. A. S., \& Peske, S. T. (2007). Expressão diferencial de isoenzimas durante o processo de germinação de sementes de arroz em grandes profundidades de semeadura. Revista Brasileira de Sementes, 29(1), 61-67. https://doi.org/10.1590/S0101-3122200700010 0009

Marcos Filho, J. (2015). Seed vigor testing: An overview of the past, present and future perspective. Scientia Agricola, 72(4), 363-374. https://doi.org/10.1590/0103-9016-2015-0007

Martins, A. B. N., Marini, P., Bandeira, J. M. De, Borba, I. C. G. de, Quineper, R. R., Moraes, D. M. de, \& Villela F. A. (2014). Vigor: Separação de lotes de sementes pela atividade respiratória. Interciencia, 39(4), 260-265.

Mendes, C. R., Moraes, D. M., Lima, M. G. S., \& Lopes, N. F. (2009). Respiratory activity for the differentiation of vigor on soybean seeds lots. Revista Brasileira de Sementes, 31(2), 171-176. https://doi.org/10.1590/S01 01-31222009000200020

Oliveira, L. M. de, Cavalheiro, V. B. D., Moraes, D. M. de, Tilmann, M. A. A., \& Schuch, L. O. B. (2015). Medição do $\mathrm{CO}_{2}$ como método alternativo para a diferenciação do vigor de lotes de sementes de melancia. Ciência Rural, 45(4), 606-611. https://doi.org/10.1590/0103-8478cr20130594

Panobianco, M., \& Marcos Filho, J. (1998). Comparação entre métodos para avaliação da qualidade físiológica de sementes de pimentão. Revista Brasileira de Sementes, 20(1), 306-310. https://doi.org/10.17801/01013122/rbs.v20n2p68-72

Santos, H. O., Von Pinho, E. V. R., Von Pinho, I. V., Dutra, S. M. F., Andrade, T., \& Guimarães, R. M. (2015). Physiological quality and gene expression. During the development of habanero pepper (Capsicum chinense Jacquin) seeds. Genetics and Molecular Research, 14(2), 5085-5098. https://doi.org/10.4238/2015. May.12.11

Santos, H. O., Von Pinho, I. V., de Oliveira Pires, E. R., da Silva V. I. F., de Carvalho, M. L. M., \& Oliveira, R. M. E. (2016). Physiological quality of hybrid maize seeds through respiratory and enzymatic activities. African Journal of Agricultural Research, 11(20), 1879-1886. https://doi.org/10.5897/AJAR2015.10457

Silva, F. de A. S., \& Azevedo, C. A. V. (2002). Versão do programa computacional Assistat para o sistema operacional windows. Revista Brasileira de Produtos Agroindustriais, 4(1), 71-78. https://doi.org/10.15871/ 1 517-8595/rbpa.v7n1p71-82

Torres, S. B., Balbino, D. O. S., Santos, W. G. N., Nogueira, N. W., Freitas, R. M. O., \& Leite, M. S. (2016). Avaliação do vigor de sementes de rúcula pela atividade respiratória. Horticultura Brasileira, 34, 561-564. https://doi.org/10.1590/s0102-053620160416

\section{Copyrights}

Copyright for this article is retained by the author(s), with first publication rights granted to the journal.

This is an open-access article distributed under the terms and conditions of the Creative Commons Attribution license (http://creativecommons.org/licenses/by/4.0/). 